\title{
MAKNA GHULUW DALAM ISLAM: BENIH EKSTREMISME BERAGAMA
}

\author{
Sihabuddin Afroni \\ Dosen Universitas Islam Negeri Syarif Hidayatullah Jakarta \\ Jalan Ir. Haji Juanda No. 95 Ciputat Tangerang Selatan Banten 15412, Indonesia \\ E-mail: sihabafroni@gmail.com
}

\begin{abstract}
This article explore the concept of ghuluw in Islam, as a seed of extremism in the name of religion. This article trace the term ghuluw in Islamic history and how Islam (through the Qur'an and Hadith) discuss this term. Etymologically, the term ghuluw means exaggerating about something. Terminologically, ghuluw means the model of excessive understanding of religious teaching deviated from its orininal meaning. Several attitudes categorized as ghuluw include: fanatic, prejudice, and blame; and even accusing of infidelity. Islam condemns all those characteristics as explain in the Qur'an and Sunna. Islam is a religion that promotes honour, peace, harmony and balance. Currently in Indonesia, however, there are two contrasting Islamic groups: on one side there has been increasing number of people who can be labeled as extremist, violent, and literalist. In another side, there is an Islamic group who tends to ignore the main principles of Islam. These two Islamic groups spread widely in Indonesian Islamic society.
\end{abstract}

Keywords:

Ghuluw; extrimism; moderation; al-tatarruf; ifrät.

\begin{abstract}
Abstrak
Tulisan ini mengkaji persoalan ghuluw sebagai benih ekstremisme dalam beragama dalam Islam. Artikel ini berusaha untuk mengunkap makna ghuluw dan kemunculan sikap tersebut dalam sejarah Islam dan bagaimana respon Al-Qur'an terhadapnya. Secara etimologi ghuluw berarti berlebih-lebihan dalam suatu perkara. Adapun Ghuluw secara istilah adalah model atau tipe keberagamaan yang mengakibatkan seseorang melenceng dari agama tersebut. Beberapa sikap yang dikategorikan sebagai ghuluw di antaranya adalah: fanatic terhadap suatu pandangan tertentu, berprasangka buruk terhadap orang/kelompok lain dan bahkan bisa sampai kepada mengkafirkan orang lain. Semua sikap ini dilarang dalam agama Islam sebagaimana dijelaskan dalam al-Qur'an dan Sunnah Rasul. Islam adalah agama rahmatan lil 'ālamīn, yang menekankan nilai-nilai kemuliaan, perdamaian, keharmonisan dan kesimbangan. Islam melarang umatnya bertindak ekstrem, melampaui batas, fanatis, dan melakukan kekerasan. Saat ini, di satu sisi, banyak pandangan keagamaan yang berkembang di tengah masyarakat mengarah pada sikap ekstrem, keras, dan literalis. Di sisi yang lain, ada kelompok yang berpandangan sangat longgar dan cenderung mengabaikan prinsip-prinsip utama dalam agama. Dua kelompok ini terus berkembang luas di kalangan umat Islam Indonesia.
\end{abstract}

Kata Kunci:

Ghuluw; ekstremisme; kemoderatan; al-tatarruf; ifrät.

DOI: http://dx.doi.org/10.15575/jw.v39i1.579

Received: November 2015 ; Accepted: December 2015 ; Published: February 2016

\section{A. PENDAHULUAN}

Islam merupakan agama peradaban. Islam bukan agama kekerasan atau agama fasis, sebagaimana dituduhkan sebagian kalangan Barat. Sebaliknya, Islam menolak kedzaliman dan teror. Kita, umat Islam, diperintakan untuk menghormati sesama manusia meski berbeda agama dan warna kulit. Seorang muslim ini laksana lebah. Ia mengonsumsi makanan yang baik, dan memproduksi sesuatu yang baik pula. Saat ia hinggap pada setangkai bunga, ia tak merusaknya. Demikianlah, Allah sudah memberikan perumpamaan umat ini sebagai suatu kebaikan yang memberi dengan penuh kasih sayang, bukan penyebar keburukan dan kekerasan.

Meskipun kita yakini Islam merupakan agama penyebar kedamaian, namun fenomena yang muncul akhir-akhir ini adalah sejumlah fakta yang menunjukkan bahwa ada sebagian umat Islam tidak memahami nilai-nilai moderat Islam dengan benar. Mereka tidak mengakui pluralitas, tidak menghargai kemajemukan yang tumbuh dalam masyarakat. Munculnya 
berbagai kelompok teroris yang mengklaim sebagai representasi umat adalah salah satu buktinya. Tidak sedikit umat Islam yang berpandangan bahwa jihad identik dengan perang. ${ }^{1}$ Beberapa kelompok garis keras sering kali dengan mudah mengkafirkan saudaranya sesama muslim hanya karena perbedaan manhaj, ideologi dan arah perjuangan. Aksiaksi bom bunuh diri di berbagai negara (termasuk di Indonesia) disinyalir didalangi oleh kelompok-kelompok ekstrem yang mengklaim berjuang atas nama agama. Bahkan saat ini kita dihadapkan kepada situasi global yang sangat krusial. Kondisi yang berimplikasi pada gangguan di bidang keamanan, politik dan sosial. Yaitu memanasnya isu Negara Islam Irak dan Suriah (ISIS) Hampir semua media menjadikannya sebagai headlines, bahkan virus fenomena ISIS ini membuat khawatir para pejabat negeri ini. Mereka khawatir bahwa ISIS dapat menjadi ancaman bagi persatuan dan keutuhan kita berbangsa dan bernegara.

Fenomena ektremisme beragama sesungguhnya bukanlah hal yang baru. Sejarah ektremisme beragama sudah sangat lama. Ekstremitas juga bukan monopoli satu agama semata. Kecenderungan sikap berlebih-lebihan mengamalkan ajaran agama, kolot, keras, kaku dan konservatif ini sudah ada sejak sebelum Islam datang. Sikap ekstrem telah menjangkiti umat-umat terdahulu. Orang-orang Yahudi dan Nasrani tercatat dalam Alquran bersikap ektrem dalam mengagungkan pemimpin mereka. Orang-orang Yahudi menyatakan Uzair adalah anak Tuhan, begitupula Umat Nasrani mentahbiskan Isa sebagai anak Tuhan. Mereka juga menciptakan kerahiban atau kependetaan yang Allah tidak pernah menurunkan keterangan tentang hal tersebut. ${ }^{2}$

Sejarah pengamalan beragama umat Islam pun tidak terbebas dari sikap ekstrem, bahkan sejak awal pertumbuhannya, yaitu sejak era Nabi Muhammad Saw. Oleh karenanya Allah Swt di dalam Alquran telah mengingatkan umat Nabi Muhammad ini agar jangan meniru

\footnotetext{
${ }^{1}$ Abdurrahman Mas'ud, Menuju Paradigma Islam Humanis (Yogyakarta: Gama Media, 2003), 38.

${ }^{2}$ Lihat Q.S. 57:27.
}

perilaku orang-orang Ahlul Kitab, terkait sikap ekstrem mereka. ${ }^{3}$ Benih-benih sifat ekstrem beberapa sahabat muncul sejak Rasulullah masih hidup. Meski generasi sahabat merupakan generasi terbaik sepanjang sejarah seperti yang diungkapkan oleh Rasullah dalam beberapa Hadisnya, namun sikap berlebih dalam menjalankan ajaran agama tetap muncul. Bagaimanapun para sahabat adalah bashar, manusia biasa yang berpotensi keliru dan subyektif dalam memahami pesan Hadis.

Pemahaman yang keliru para sahabat lazimnya didorong oleh ghirah semangat keagamaan yang tinggi. Semisal kecintaannya yang berlebih pada sosok pribadi Nabi atau sangat cinta pada amalan ibadah tertentu dan ingin menjadi hamba terbaik. Niat baik mereka tidak selamanya sejalan dengan syariat. Mereka terkadang membuat kekeliruan. Akan tetapi kekeliruan pada sahabat dapat langsung diredam dan dieliminir oleh Rasulullah Saw. Bilamana muncul pengamalan agama yang keliru, Rasulullah segera memberikan terapi, mengingatkan tentang bahaya sikap ekstrem serta menunjukkan praktik yang sesuai dengan Sunah. Keberadaan Rasulullah Saw di tengahtengah mereka sangat efektif menghambat berkembangnya sifat ekstrem di masa awal Islam. Hal ini dapat difahami karena Rasulullah merupakan sosok sentral yang wajib ditaati oleh seluruh umat Islam. Di era sahabat, sepeninggal Rasulullah muncul berbagai pemahaman dan praktik yang tidak selaras dengan ajaran dan karakteristik Islam.

Bahkan di era sahabat, pemahaman yang keliru bukan lagi dalam tataran individu namun sudah mengkristal menjadi kelompok. Seperti munculnya kelompok Khawarij, Qadariyah, Syiah dsb. Sikap berseberangan bukan hanya merambah wilayah amaliyah ibadah, namun juga hal yang menyangkut i'tiqādiyyah atau yang sering dibahas dalam ilmu Kalam. Hal yang memprihatinkan pula, dalam lintas sejarah umat Islam telah terjadi banyak pertumpahan darah di antara kelompok-kelompok yang berbeda sebagai

\footnotetext{
${ }^{3}$ QS. 9:31 dan QS. 5:77.
} 
upaya untuk meneguhkan pemahaman masingmasing.

Oleh karena itu, persoalan yang menjadi fokus penelitian ini adalah:

1. Apa yang menjadi ciri-ciri ektremitas dalam beragama itu?

2. Faktor-faktor apa yang dapat menimbulkan ekstremitas dalam beragama?

3. Bagaimana sikap ghuluw sebagai benihbenih ekstremitas beragama dalam Islam muncul sejak Rasulullah Saw. dan pada sahabat?

Jadi, tulisan ini berupaya untuk mendokumentasikan peristiwa-peristiwa di masa Rasulullah Saw yang dinilai sebagai cikal bakal atau benih ektremisme beragama. Penulis melakukan telaah terhadap teks-teks Hadits dan riwayat sahabat yang memuat sikap pengamalan agama yang berlebihan pada generasi awal Islam. Penulisan makalah ini penulis anggap penting untuk memberi wacana kepada pembaca bahwa permasalahan ektremitas beragama muncul seiring dengan kemunculan agama itu sendiri. Pemahaman yang tidak utuh dan motif ingin sesempurna mungkin mengamalkan ajaran agama sering menjadi faktor utama pemeluk agama terjerumus dalam tindakan ekstrem. Pemahaman ekstrem adalah sebuah realitas yang muncul sepanjang zaman.

Dalam konteks kekinian, kelompok garis keras, radikal yang masih eksis sampai saat ini tidak akan efektif diberantas dengan tindakan represif. Karena sikap mereka berbasis keyakinan. Kaum ekstremis radikal seringkali menyandarkan aksinya pada teks-teks keagamaan, meskipun teks-teks tersebut mengalami deviasi dalam penafsirannya. Oleh karena itu upaya deradikalisasi mereka haruslah dimulai dari dalil-dalil otentik yang bersumber dari Alquran dan Hadis. Semisal mengungkapkan riwayat, bukti dan fakta bahwa ektremisme sejak awal ditentang oleh Nabi Muhammad Saw. Islam adalah agama wasatiyyah (tengah, moderat), mudah dan realistis. Sikap ekstrem, keras dan kaku dalam beragama sangatlah ditentang dalam ajaran Islam. Kecenderungan sikap dan pemikiran ekstrem, radikal, intoleran di kalangan sebagian umat Islam yang berkembang sampai saat ini, dapat dilawan dan dicegah dengan memaparkan fakta sejarah bahwa agama ini berjalan atas prinsip kemudahan dan keseimbangan. Sejumlah Hadis Nabi Muhammad Saw dalam usaha memerangi ekstremitas beragama yang penulis paparkan dalam makalah ini dapat menjadi panduan para pendidik untuk menyiapkan generasi mendatang yang toleran dan damai.

\section{B. HASIL DAN PEMBAHASAN \\ 1. Pengertian Ghuluw (Ekstrem) dan Ciri- Ciri Ekstremitas Beragama}

Ektrem menurut Kamus Besar Bahasa Indonesia berarti, 1. Paling ujung, paling tinggi, paling keras; 2. Sangat keras, sangat teguh, fanatik. Ekstremitas adalah hal (tindakan, perbuatan) yang melewati batas. ${ }^{4}$ Dalam terminologi syariat, sikap ektrim sering juga disebut ghuluw yang bermakna berlebihlebihan dalam suatu perkara. Atau bersikap ekstrem pada satu masalah dengan melampaui batas yang telah disyariatkan. ${ }^{5}$ Adapun ghuluw secara istilah adalah model atau tipe keberagamaan yang mengakibatkan seseorang melenceng dari agama tersebut. ${ }^{6}$ Disamping itu, ada istilah al-tatarruf dalam bahasa Arab modern yang menunjuk pada kata ektrim. Altatarruf, menurut etimologis bahasa Arab bermakna berdiri di tepi, jauh dari tengah. Dalam bahasa Arab awalnya digunakan untuk hal yang materil, misalnya dalamberdiri, duduk atau berjalan. Lalu kemudian digunakan juga pada yang abstrak seperti sikap menepi dalam beragama, pikiran atau kelakuan. Beberapa istilah lain yang berkonotasi serupa dengan ghuluw antara lain tanattu' (sikap yang keras), ifrät (mempersempit), tashaddud (menyusah sesuatu) atau takalluf (memaksakan diri).

\footnotetext{
${ }^{4}$ Tim Penyusun Kamus Bahasa, Kamus Besar Bahasa Indonesia, Edisi 3 (Jakarta: Balai Pustaka, 2002), 292.

${ }^{5}$ Ibnu Hajar Asqalani, Fathul Bāri, vol.12 (Kairo: Darul Rayyan Lil Turats, 1988).

${ }^{6}$ Ibnu Manzur, Lisānul 'Arab, vol. 15 (Bairut: Dār al- Ihyya Turāth al-'Arabī, 1985), 131.
} 
Dalam lintas sejarah, sikap ekstrem atau ghuluw seringkali terjadi dalam pengamalan ajaran agama. Secara garis besar sikap ekstrem terbagi menjadi dua macam. Pertama, ekstrem atau ghuluw dalam aspek akidah, seperti ghuluw orang-orang Nasrani dengan keyakinan Trinitasnya. Begitu besar pengagungan mereka terhadap Nabi Isa As. sampai kemudian mereka mentahbiskannya sebagai Tuhan. Para penganut Syiah Rafidhah bersikap ghuluw dengan cara meninggikan derajat Ali sampai sebagian diantaranya menganggapnya lebih baik dari Abu Bakar, Umar dan Utsman. Sebagian lagi bahkan menganggapnya lebih baik dari Rasulullah Saw. Lebih dari itu, sebagian orang Syi'ah bahkan menganggap Ali sebagai titisan Allah. Contoh lainnya adalah ghuluw-nya orang-orang Sufi yang menganggap suci para pemimpinnya yang dianggap tak mungkin keliru. Juga sikap berlebih-lebihan dalam mengkafirkan kelompok lain dengan landasan yang samar dan meragukan. Kedua, Sikap ekstrem dalam praktik/amalan agama, contohnya berlebih-lebihan dalam masalah ibadah salat sepanjang malam tanpa tidur, puasa terus menerus tanpa jeda hari. Termasuk juga pandangan kelompok tertentu yang menjadikan perkara yang tidak wajib atau pun Sunah, menjadi wajib atau disunahkan. Terkadang juga dalam bentuk menjadikan perkara yang mubah menjadi makruh ataupun haram. Menganggap diri mereka sebagai pemegang kebenaran. Meremehkan para ulama yang tidak sefaham dengan mereka dan menjauhinya.

Dalam kaitan ini Yusuf Qardhawi menyatakan bahwa kelompok-kelompok ekstrem mempunyai beberapa ciri. Di antaranya adalah:

1. Fanatik terhadap salah satu pandangan.

Sikap fanatik berlebihan ini mengakibatkan seorang akan menutup diri dari pendapat kelompok lain dan menyatakan bahwa pandangannyalah yang paling benar. Pandangan yang berbeda adalah salah. Padahal para salaf shaleh bersepakat menyatakan, bahwa setiap orang diambil dan diting- galkan pandangannya kecuali Rasulullah Saw.

2. Cenderung mempersulit.

Secara pribadi boleh saja seseorang beribadah tidak menggunakan keringanan padahal itu dibolehkan. Akan tetapi kurang bijak apabila ia mengharuskan orang lain mengikutinya. Padahal kondisi dan situasi orang lain berbeda atau tidak memungkinkan. Rasulullah secara pribadi adalah orang yang sangat kuat beribadah, namun manakala ia mengimami salat di masjid maka beliau memperhatikan kondisi jamaah dengan memperpendek bacaan.

3. Berprasangka buruk kepada orang lain.

Sikap ini muncul karena ia merasa paling benar dan menjadikan ia berprasangka buruk kepada orang lain. Seakan-akan tidak ada kebaikan kepada orang lain. Sebagai contoh, ada seorang khatib tidak memegang tongkat saat berkhutbah, atau ada orang yang makan tidak di lantai. Maka kemudian ia dituduh sebagai orang yang tidak mengikuti sunah atau mencintai Rasul. Sikap ini lahir dari rasa ujub atau merasa dirinyalah yang paling benar dan ujub itulah sebenarnya merupakan benih dari kebinasaan seseorang.

4. Suka mengkafirkan orang lain.

Sikap ghuluw yang paling berbahaya tatkala sampai ke tingkat mengkafirkan orang lain, bahkan menghalalkan darahnya. Ini yang pernah terjadi pada kelompok khawarij. Pandangan ghuluw ini pula yang mengakibatkan terbunuhnya dua orang khalifah; Usman bin Affan dan Ali bin Abi Thalib. Apa yang dulu dilakukan kelompok Khawarij saat ini juga banyak ditemukan yaitu dengan mengkafirkan para penguasa di negara-negara muslim dengan alasan tidak menerapkan hukum Tuhan.

Bahkan mereka mengkafirkan para ulama yang enggan mengkafirkan para penguasa tersebut. Padahal sesuai ajaran Rasulullah Saw, seseorang tidak boleh dengan mudah mengkafirkan orang lain, sebab berimplikasi hukum yang panjang seperti halal 
darahnya, dipisah dari istrinya, tidak saling mewarisi dan sebagainya. ${ }^{7}$

Adapun batasan-batasan suatu pemahaman maupun sikap dapat dikategorikan sebagai bentuk ekstrem, di antaranya;

1. Pembatasan pengertian ghuluw harus didasarkan kepada Alquran dan sunah. Dalam artian, untuk menghukumi sebuah sikap merupakan ghuluw hendaklah berdasarkan dalil dari Alquran dan sunah bukan berdasarkan hawa nafsu, prasangka apalagi kepentingan musuh-musuh agama.

2. Ghuluw dalam kehidupan kontemporer merupakan realitas yang tidak perlu dipungkiri. Hal ini dapat disebabkan oleh fanatisme buta dan sempitnya wawasan. Oleh sebab itu, setiap sesuatu haruslah dipandang secara integral dan berdasarkan ilmu agar menghasilkan pandangan yang tengah seimbang dan moderat. Tidak terjerumus dalam ifrät (menyempitkan) maupun sebaliknya tafrit (meremehkan).

3. Kondisi agama seseorang dan masyarakat sekitarnya, kuat dan lemahnya kondisi tersebut mempunyai pengaruh untuk menghukumi seseorang sebagai palaku ghuluw, setengah ghuluw atau sama sekali tidak. Sebab, barang siapa yang berpegang teguh terhadap agama dan hidup ditengah masyarakat yang memiliki komitmen tinggi terhadap agama, maka perasaannya langsung bangkit jika mendapati sebuah kemungkaran atau pengabaian dalam penegakkan hukum-hukum syariat. Sementara orang yang tidak ambil pusing dan hidup ditengah masyarakat yang acuh tak acuh terhadap agama, maka perasaannya menjadi kebal, tidak melihat suatu dosa sebagai sebuah kesalahan namun disisi lain ia melihat komitmen seseorang terhadap agamanya sebagai sebuah ghuluw atau sikap ekstrem.

4. Menghukumi sesuatu sebagai ghuluw terhadap seseorang atau penafiannya berbeda-beda menurut kondisi dan lingkungan. Melawan penguasa zhalim yang me-

\footnotetext{
${ }^{7}$ Yusuf Qardhawi, Al-Khasā'is al-'Ammah li alIslām (Kairo: Maktabah Wahbah, 1996), 43.
}

musuhi Islam mungkin dianggap jihad. Hal ini terjadi jika penguasa yang diperangi itu melakukan kekufuran yang nyata, lengkap dengan bukti-buktinya. Tapi memungkinkan juga disebut ghuluw jika penguasa yang hendak diperangi itu tidak melakukan kekufuran dan juga tidak ada bukti atas kekufurannya. Semua ini tergantung kepada perbedaan kondisi dan situasi. ${ }^{8}$

\section{Faktor Timbulnya Sikap Ekstrem}

Dalam sebuah disertasi yang ditulis oleh Abdurrahman bin Mu'alla al Luwaihiq dari Universitas Imam Muhammd bin Su'ud, Mushkilāt al-Ghuluw fí al-Dìn fí al-'Așr alHädir, secara terperinci mengidentifikasikan faktor-faktor yang menyebabkan sikap ekstrem/ghuluw dalam lintas sejarah umat Islam. Ia mengklasifikasikannya dalam tiga sebab utama; Pertama, sebab-sebab yang berkaitan dengan metodologi ilmiah. Kedua, sebab-sebab yang berkaitan dengan aspek kejiwaan dan pendidikan. Ketiga, sebab-sebab yang berkaitan dengan aspek sosial dan problematika dunia. ${ }^{9}$

Faktor pertama yang berkaitan dengan metodologi ilmiah yang dimaksud melingkupi kebodohan dalam ajaran Islam. Ghuluw seringkali muncul dari seseorang yang terlalu semangat mengamalkan ajaran agama tapi minim ilmu. Ia mempelajari ajaran Islam secara parsial. Belum mempelajari Alquran dan Hadis secara menyeluruh namun cepat menyimpulkan sesuatu hukum berdasar pengetahuannya yang minim. Menentukan hukum secara langsung dari nas dengan metode yang kaku dalam memahami nas. Tidak mengerti tujuan-tujuan syariat, pemahaman yang literal, tidak peduli dengan konteks nas, kondisi manusia dan perubahan zaman. Kelompok Ghuluw seringkali mengikuti nas-nas yang mutashabihàt dan tidak mampu mengkompromikan di antara beberapa dalil. Ditunjang dengan sikap fanatik

\footnotetext{
${ }^{8}$ Yusuf Qardhawi, Șậwah Al-Islāmiyyah Bayna Al-Jumūd Wa Al-Tatarruf (Kairo: Dar el Shorouk, 2001).

${ }^{9}$ Abdurrahman bin Mu'alla Luwaihiq, Ghuluw Benalu Dalam BerIslam (Jakarta: Darul Falah, 2014).
} 
mereka terhadap golongan, mazhabnya, sehingga ia sulit menerima kebenaran dari orang lain.

Faktor Kedua yang berkaitan dengan aspek kejiwaan dan pendidikan mencakup tabiat dan lingkungan yang keras. Hal ini dapat kita lihat munculnya sikap ghuluw di kalangan Khawarij. Kelompok puritan Khawarij keba-nyakan berasal dari suku Badui Arab yang keras dan hidup nomaden mengarungi kehidupan padang pasir yang ganas. Padang pasir yang tandus membuat mereka bersifat sederhana dalam cara hidup dan pemikiran, tetapi keras hati serta berani, dan bersikap merdeka, tidak bergantung pada orang lain. Perubahan agama tidak membawa perubahan pada sikap-sikap kebaduwian mereka. Mereka tetap bersikap bengis, suka kekerasan dan tak gentar mati. Ajaran Islam mereka pahami apa adanya dan apa yang ada dalam Alquran dan Hadis mereka pahami sesuai dengan lafalnya. Mereka seringkali lebih mengikuti hawa nafsunya untuk melawan dan bermusuhan dengan sesama kaum muslimin yang dianggap oleh mereka sudah melenceng dari ajaran Islam.

Faktor yang ketiga berhubungan dengan aspek sosial, ekonomi, politik dan problematika dunia. Ketidakpuasan terhadap kondisi umat Islam yang terpuruk secara sosial dan ekonomi sering menjadi alasan kelompok radikal untuk bertindak ekstrem. Rusaknya akidah umat, hilangnya syariat Allah dalam aspek hukum di mayritas negara-negara kaum muslimin mendorong mereka ingin memulihkannya. Apalagi mereka mensinyalir bahwa keterpurukan umat lebih disebabkan oleh hegemoni dan ketidakadilan kekuatan asing dalam memperlakuakan dunia Islam. Meluasnya sekulerisasi, kebobrakan akhlak, hilangnya peran ulama dalam masyarakat menyebabkan sebagaian kaum muslimin mengasingkan diri dan bersikap keras terhadap segala hal yang terafiliasi dengan asing (Barat).

Muhammad al-Zuhaili dalam bukunya Moderat dalam Islam, sikap ekstrem berlebihlebihan dalam beragama itu paling tidak karena dua faktor. Pertama, terlalu semangat/ tamak beragama, tetapi minim ilmu. Orang yang semangat tadi beranggapan bahwa jalan yang ia tempuh adalah, jalan yang benar, sarana satu-satunya, dan sarana yang kokoh untuk meraih apa yang ada di sisi Allah. Dia beranggapan bahwa orang di luar diri dan golongannya kurang atau berada di bawahnya dalam hal beramal. Sikap beragama ini tidak dilandasi dengan ilmu yang memadai dan sikap bijaksana maka yang akan timbul adalah sikap ekstrem. Kedua, dosa dan kesalahan. Dosa dan kesalahan masa lalu akan menjadi pendorong sikap berlebih-lebihan dalam beragama karena perasaan khawatir terhadap masa lalu yang kelam. Juga khawatir terhadap akibat-akibat dari dosa dan amalanamalan buruk yang telah dilakukannya. Kekhawatiran dan penyesalan akan dosa-dosa itu kemudian diikuti dengan usaha menghapus dosa dalam waktu cepat. Karena terlalu tergesa-gesa dengan harapan dosa agar cepat terhapus, mereka keliru menemukan jalan yang normal. Mereka berusaha membuat tambahan dalam agama, bersikap kaku dalam menjalankan hukum-hukum, keras dalam beribadah, dan melewati batasan yang telah digariskan dalam menjalankan hukum dan ajaran agama. ${ }^{10}$

Menurut Tarmizi Taher, ada beberapa faktor yang menyebabkan lahirnya faham ekstrem. Pertama, karena faktor modernisasi yang dapat dirasakan dapat menggeser nilainilai agama dan pelaksanaanya dalam agama. Kedua, karena pandangan dan sikap politik yang tidak sejalan dengan sikap dan politik yang dianut penguasa. Ketiga, karena ketidak puasan mereka terhadap kondisi sosial, ekonomi, politik dan sebagainya yang berlangsung di Indonesia. Keempat, karena sifat dan karakter dari ajaran Islam yang dianut kelompoknya cenderung bersifat rigid (kaku) dan difahami secara literalis. ${ }^{11}$

\footnotetext{
${ }^{10}$ Muhammad Zuhaili, Moderat dalam Islam (Jakarta: Penerbit Akbar Media, 2012), 27.

${ }^{11}$ Tarmizi Taher, "Anatomi Radikalisme Keagamaan dalam Sejarah Islam," in Radikalisme Agama, ed. Bahtiar Effendi dan Hendro Prasetyo (Jakarta: PPIM, 1998), 6.
} 


\section{Larangan Bersikap Ekstrem dalam Alquran dan Hadis}

Islam mensyariatkan umatnya untuk menegakkan keseimbangan dalam segala hal. Alquran dan Hadis sebagai dua sumber utama Islam menegaskan hal tersebut. Dalil-dalil syariat selalu menyeru umat Islam bersikap adil, moderat, seimbang dan melarang berlebih-lebihan, mempersulit dan memperberat yang diistilahkan dengan ekstrem. Dalam upaya memberikan terapi umat Nabi $\mathrm{Mu}-$ hammad Saw supaya tidak terjerumus dalam perilaku ekstrem, Alquran memberikan berbagai panduan diantaranya :

1. Mensifati umat Islam sebagai umatan wasatan.

Dalam QS. 2: 143. "Demikianlah Kami jadikan kamu umat yang adil dan moderat (wasathan) supaya kalian menjadi saksi atas manusia."

Imam Ibnu Jarir Al-Ṭabari dalam tafsirnya, Jāmi' Al-Bayān fì Ta'wīl Ayat alQur'ān berkata:

Aku berpendapat bahwasannya Allah mensifati umat ini dengan wasat karena posisi pertengahan mereka dalam beragama, mereka bukanlah para ekstremis, sebagaimana ekstremnya kalangan Nasrani dalam peribadatan dan perkataan mereka tentang Isa, dan mereka bukanlah para ekstremis sebagaimana ekstremnya kalangan Yahudi yang telah merubah-ubah kitab Allah, membunuh para Nabi, berdusta pada Tuhannya, serta kufur kepada-Nya. Akan tetapi mereka adalah orang-orang pertengahan yang dapat bersikap adil dan proporsional dalam hal tersebut. Oleh sebab itu Allah mensifati mereka dengannya, karena sesungguhnya setiap perkara yang paling disukai Allah adalah perkara yang pertengahan. ${ }^{12}$

Islam merupakan agama yang senantiasa menjaga keharmonisasan dan keseimbangan antara kebutuhan jasmani dan ruhani, antara kebutuhan individu dan masyarakat, dan antara kebutuhan dunia dan akhirat. Islam me-

${ }^{12}$ Ibnu Jarī Tabari, Jāmi' Al-Bayān Fì Ta’wīl $\bar{A} y i$ Al-Qur'ān, Vol. 4 (Bairut: Dār al-Ihyya li al-Ṭurāth, t.t.). ngajarkan umatnya untuk selalu berada di tengah dan menempuh jalan tengah, dan sikap itu harus direalisasikan dalam segala hal, sebagaimana Hadis Rasulullah Saw. yang diriwayatkan oleh Imam Ahmad, "Sebaikbaiknya perkara adalah yang pertengahan." Dengan kata lain, sebagai agama pilihan, Islam melarang umatnya bertindak berelebihan, semena-mena, melampaui batas, bertindak fanatis, mendahulukan kepentingan individu dan golongan di atas kepentingan orang banyak, apalagi berlaku ekstrem dan melakukan kekerasan.

2. Mengingatkan bahwa kehancuran umatumat terdahulu akibat sifat ekstrem.

Dalam QS. 5:77, Allah berfirman:

Wahai ahli Kitab janganlah kalian bersikap ekstrem (ghuluw) dalam agama kalian. Dan janganlah kalian mengikuti hawa nafsu kaum sebelum kalian yang telah sesat dan menyesatkan banyak orang.

Dalam Tafsir Ibnu Kathir dinyatakan bahwa sikap ghuluw melanda umat terdahulu utamanya dalam masalah Aqidah. Mereka melampaui batas dalam keimanan. Seperti orang Yahudi yang menyatakan bahwa Uzair adalah anak Tuhan, sedangkan orang Nasrani mengklaim bahwa Nabi Isa As adalah anak Allah. Mereka telah sesat dari keadilan yang dibawa oleh Nabi Muhammad Saw. ${ }^{13}$

3. Melarang manusia untuk merusak di atas bumi, karena dunia juga merupakan garapan orang beriman, disamping akhirat.

Dalam QS. 28: 77, Allah berfirman:

Dan carilah pada apa yang telah dianugerahkan Allah Swt kepadamu (kebahagiaan) negeri akhirat, dan janganlah, kamu melupakan bagianmu dari (kenikmatan) duniawi dan berbuat baiklah (kepada orang lain) sebagaimana Allah telah berbuat baik kepadamu dan janganlah kamu berbuat kerusakan di atas permukaan bumi. Sesungguhnya Allah tidak menyukai orang-orang yang berbuat kerusakan.

Ayat ini menyatakan bahwa kita diminta untuk jangan melupakan bagian dunia. Kita

13 'Imādu al-Dīn Abu al-Fida' Ibnu Kathīr, Tafsīi Al-Qur'ān Al-'Azìm, Vol. 2 (Kairo: Dār al-Kutūb alMișriyah, 1988). 
tidak boleh melupakan hal-hal yang telah Allah bolehkan (bahkan diperintahkan); seperti makanan, minuman, pakaian, tempat tinggal (untuk istirahat), serta pernikahan (untuk memperbanyak keturunan; dan selainnya). Dalam menafsirkan ayat ini Imam Ibnu Kathīr juga menenkankan:

Janganlah semangatmu (dalam beramal saleh) justru menjerumuskanmu dalam berbuat kerusakan (terhadap orang lain), sesungguhnya Allah tidak menyukai para pembuat kerusakan.

Rasullullah Saw membawa misi penting untuk memperbaiki akhlak umat manusia. Beliau menjadi teladan pengamalan agama yang sesuai dengan kehendak Allah Swt. Ketika terjadi penyimpangan atau kekeliruan dalam perilaku sahabat, maka beliau segera meluruskannya. Begitu pula hal yang terkait dengan sikap ekstrem dalam beragama. Banyak Hadis Nabi Muhammad Saw yang melarang kita bersikap ghuluw atau ekstrem dalam beragama, di antaranya;

a. Hadis yang diriwayatkan oleh Abdullah bin Mas'ud bahwasannya Nabi Muhammad Saw bersabda: "Binasalah orang-orang yang mutanatti'un! Binasalah orang-orang yang mutanatti'un! Binasalah orang-orang yang mutanatti'un!!" (HR. Muslim). ${ }^{14}$

Imam Nawawi dalam syarah Sahih Muslim berkata,"Al-Mutanatti'un adalah orang-orang yang keras, mempersulit ketika membahas suatu permasalahan, sehingga penafsiran dan pendapatnya melampaui batas".

b. Hadis yang diriwayatkan oleh Abu Hurairah ra, bahwasannya Rasulullah Saw bersabda:

Agama itu mudah, Tidak ada orang yang memberat-beratkan (masalah) agama, melainkan ia akan dikalahkan. Maka (dalam beramal) hendaklah pertengahan, dekatkan (kepada Allah), bergembiralah kalian. Mohonlah pertolongan (pada Allah Swt) di waktu pagi, sore dan sedikit waktu malam. (HR. Bukhari). ${ }^{15}$

\footnotetext{
${ }^{14}$ Islam Web, "Sahih Muslim, Hadis No. 4829," Islamweb.net, t.t.

${ }^{15}$ Muhammad bin Isma'il al-Ju'fi Al-Bukhari, “AlJāmi’ Al-Șahih, Hadis No.38," t.t.
}

\section{c. Bersabda Nabi SAW:}

Janganlah kalian memberat-beratkan suatu permasalahan agama, karena suatu kaum telah memperberat diri mereka sendiri sehingga Allah pun memperberat atas mereka (HR Abu Dawud). ${ }^{16}$

d. Nabi Muhammad Saw pun senantiasa menasihati para sahabatnya saat berangkat untuk menyiarkan Islam dengan sabdanya: Permudahlah oleh kalian semua dan jangan dipersulit, gembirakanlah mereka dan jangan disusahkan, bersepakatlah dengan mereka dan jangan berselisih." (HR Bukhari). ${ }^{17}$

e. Nabi Saw bersabda:

Orang yang terbaik di antara kalian bukanlah orang yang meninggalkan akhiratnya demi dunianya, juga bukan pula orang yang meninggalkan urusan dunianya demi akhiratnya." (HR. al-Dailami dan lbnu Asakir). ${ }^{18}$

Masih banyak Hadis Nabi yang mencela sikap berlebihan dalam beragama. Nas-nas yang dipaparkan di atas, penulis nilai telah cukup menggambarkan betapa Islam tidak menghendaki kita mempersempit dan menyusahkan urusan agama. Agama Islam diturunkan Allah dengan kemudahan. Imam Ibnu Jarìr Al-Ṭabari dalam tafsirnya, Jämi' alBayān fì Ta'wīl Ayi al-Qur'ān berkata:

$\mathrm{Aku}$ berpendapat bahwasannya Allah mensifati umat ini dengan wasat karena posisi pertengahan mereka dalam beragama, mereka bukanlah para ekstremis, sebagaimana ekstremnya kalangan Nasrani dalam peribadatan dan perkataan mereka tentang Isa, dan mereka bukanlah para ekstremis sebagaimana ekstremnya kalangan Yahudi yang telah merubah-ubah kitab Allah, membunuh para Nabi, berdusta pada tuhannya, serta kufur kepada-Nya. Akan tetapi mereka adalah orang-orang pertengahan yang dapat bersikap adil dan proporsional dalam hal tersebut. Oleh

\footnotetext{
16،'Sunan Abu Daud, Hadis No.4260,” Islamweb.net, t.t.

17،Sahih Bukhari, Hadis No.68," t.t.

${ }^{18}$ Yazid bin Abdul Qadir Jawas, "Larangan Ghuluw Dalam Beragama," manhaj.or.id, t.t.
} 
sebab itu, Allah mensifati mereka dengannya, karena sesungguhnya setiap perkara yang paling disukai Allah adalah perkara yang pertengahan. ${ }^{19}$

\section{Benih Ekstremisme Beragama pada Masa Rasulullah Saw.}

Sepanjang lintasan sejarah umat Islam selalu saja ada sikap-sikap beragama yang cenderung ekstrem, baik dalam tataran tindakan kongkrit maupun pemahaman terhadap hukum-hukum agama. Dalam konteks ini Ibn Qayyim Al-Jauziyah berkata:

Allah tidak memerintahkan sesuatu melainkan setan mempunyai dua bisikan, kepada keteledoran dan pengabaian atau kepada berlebih-lebihan dan ghuluw. Agama Allah ada di antara keduanya, antara yang teledor dan yang ghuluw". ${ }^{20}$

Sejumlah kisah terjadi pada masa Rasulullah Saw. memperlihatkan bahwa sikap ekstrem sudah mulai muncul dalam praktek beragama sebagian sahabat Nabi. Meskipun penyimpangan ini masih dalam tataran individu dan skala yang kecil. Umumnya kekeliruan terjadi lantaran semangat yang kuat dari sahabat ingin mengamalkan Islam secara total. Ketika gejala ekstremitas ini muncul di hadapan Nabi Saw, maka Nabi segera meluruskan dan para sahabatpun mengoreksi kekeliruan mereka, dan kembali istiqāmah ke jalan yang lurus.

Satu yang harus diketahui bahwa Allah Swt menjadikan para sahabat tidak dalam keadaan yang maksum (terjaga dari kesalahan). Justru Allah Swt menjadikan mereka semua manusia yang bisa bersalah sebagai teladan bagi umat setelahnya, serta memperlihatkan kepada kita contoh terbaik dari lingkungan generasi terbaik. Seandainya Allah Swt menjadikan para sahabat terjaga dari kesalahan dan tidak ada dari mereka yang berbuat pelanggaran, maka dari mana kita belajar caranya berinteraksi dengan pelanggar syariat? Itulah hikmah Allah Swt tidak menjadikan para

\footnotetext{
${ }^{19}$ TTabari, Jāmi' Al-Bayān Fì Ta’wīl Āyi Al-Qur'ān.

${ }^{20}$ Ibn al-Qayyim. Jauziyyah, Madarij Al-Sālikinn Bayna Manāzil Iyyāka Na’budu Wa Iyyāka Nasta'īn (Kairo: Darut Turath, 1992).
}

sahabat itu ma'ṣum. Yaitu agar kita mengerti dan tahu bagaimana tuntunan yang baik menghadapi seorang pelaku maksiat atau penyimpangan.

Berikut sejumlah riwayat yang mengindikasikan munculnya benih-benih ekstremitas beragama di masa Rasulullah Saw:

a. Kisah Dzul Khuwaisirah Menghardik Nabi Muhammad Saw.

Awal mula sikap dan pemikiran ekstrem pada masa Rasulullah Saw. tercatat dalam sejarah, muncul dari sosok yang bernama Dzul Khuwaisirah. Ketika Rasulullah Saw. membagi-bagikan harta rampasan pasca perang Hunain. Beliau memberikan seratus ekor unta kepada Aqra' bin Habis dan Uyainah bin Haris. Beliau juga memberikan kepada beberapa orang dari tokoh Quraisy dan pemuka-pemuka Arab lebih banyak dari yang diberikan kepada yang lainnya. Melihat hal ini, Dzul Khuwaisirah dengan mata melotot dan urat lehernya menggelembung berkata: "Demi Allah ini adalah pembagian yang tidak adil dan tidak mengharapkan wajah Allah". Atau dalam riwayat lain dia mengatakan kepada Rasulullah Saw.: "Berbuat adillah, karena sesungguhnya engkau belum berbuat adil!".

Sungguh, kalimat tersebut bagaikan petir di siang bolong. Pada masa generasi terbaik dan di hadapan manusia terbaik pula, ada seorang yang berani berbuat lancang dan menuduh bahwa Rasulullah tidak berbuat adil. Mendengar ucapan ini Rasulullah Saw dengan wajah yang memerah bersabda:

"Siapakah yang akan berbuat adil jika Allah dan rasul-Nya tidak berbuat adil? Semoga Allah merahmati Musa. Dia disakiti lebih dari pada ini, namun dia bersabar." (HR. Bukhari Muslim)

Saat itu Umar bin Khathab meminta izin untuk membunuhnya, namun Rasulullah shalallahu 'alaihi wasallam melarangnya. Beliau mengabarkan akan munculnya dari turunan orang ini kaum reaksioner sebagaimana disebutkan dalam beberapa riwayat. Para ulama banyak yang menyatakan generasi penerus Dzul Khuwaisirah inilah yang dikemudian hari menjelma menjadi kelompok Khawarij yang 
radikal. Dalam banyak riwayat Hadis Rasulullah menggambarkan ciri-ciri kelompok tersebut:

Sesungguhnya akan keluar dari keturunan orang ini satu kaum; yang membaca Alquran, namun tidak melewati kerongkongannya. Mereka membunuh kaum muslimin dan membiarkan para penyembah berhala. Mereka akan keluar dari Islam ini sebagaimana keluarnya anak panah dari buruannya. Jika sekiranya aku menemui mereka, pasti aku bunuh mereka seperti terbunuhnya kaum "Aad." (HR. Bukhari Muslim)

Kisah memilukan dari kelompok Khawarij ini digambarkan dalam kitab al-Milāl wa alNiḥāl karya Syahrastani. Disebutkan mereka telah melakukan kezaliman terhadap seorang yang saleh dan keluarganya yaitu Abdullah anak dari sahabat Khabbab bin Art ra. Mereka membantainya, merobek perut istrinya dan mengeluarkan janinnya. Setelah itu dalam keadaan pedang masih berlumuran darah, mereka mendatangi kebun kurma milik seorang Yahudi. Pemilik kebun ketakutan seraya berkata: "Ambillah seluruhnya apa yang kalian mau!" Pimpinan khawarij itu menjawab dengan arif: "Kami tidak akan mengambil-nya kecuali dengan membayar harganya".

Kelompok ini sungguh sangat membahayakan kaum muslimin, terlepas dari niat mereka dan kesungguhan mereka dalam beribadah. Mereka menghalalkan darah kaum muslimin dengan kebodohan. Untuk itu mereka tidak segan-segan melakukan teror, pembunuhan, pembantaian dan sejenisnya terhadap kaum muslimin sendiri. Kebanyakan di antara mereka berusia muda, dan bodoh pemikirannya karena kurangnya kedewasaan mereka. Mereka hanya mengandalkan semangat dan emosinya, tanpa dilandasi oleh ilmu dan pertimbangan yang matang.

b. Kisah Tiga Sahabat Rasulullah Saw yang

Bertekad Ibadah Terus Menerus.

Benih-benih sikap ekstrem tersebut pernah diperlihatkan tiga orang sahabat Nabi Saw ketika mereka bertanya kepada Siti Aisyah RA, istri Rasul tentang ibadah beliau. Diceritakan oleh Siti Aisyah bahwa Rasulullah
Saw adalah sosok yang gemar beribadah. Hingga akhirnya salah satu di antara mereka berkata: "Maka aku akan selalu salat malam dan tidak akan tidur". Yang kedua berkata, "Adapun aku, maka aku akan berpuasa sepanjang hari dan tidak akan berbuka." Dan yang ketiga berkata, "Sedangkan aku tidak akan menikah selama-lamanya". Mendengar hal tersebut lantas Rasulullah melarang mereka melakukan itu dan berkata: "Sedangkan aku, maka aku salat malam dan tidur, berpuasa dan berbuka, dan menikahi wanita. Barangsiapa yang membenci Sunahku maka ia bukan dari golonganku." (HR. Ahmad, 'Abd bin Humaid, Bukhari, Muslim, Nasa'i, dan Ibnu Hibban dari Anas bin Malik ra).

Hadis tersebut mengajak dan mendorong pada keseimbangan tawazun dalam segala tuntutan dan kewajiban. Hal ini sebagai langkah antisipatif atas tindakan ekstrem (ghuluw) yang mereka lakukan dengan membebankan sesuatu hal yang sebenarnya tidak diwajibkan atas mereka serta mencegah hal yang semestinya tidak pernah diharamkan atas mereka. Selanjutnya Nabi Saw. memberikan bimbingan bahwa esensi takut dan takwa kepada Allah bukanlah dengan bersikap ekstrem, berlebihan atau meremehkan, melainkan dengan sikap yang seimbang terhadap aneka ragam tuntutan syariat. ${ }^{21}$

c. Kisah Ibnu Abbas Menolong Rasulullah,

Mengambilkan Batu Kerikil Besar untuk Jumrah di Hari Aqabah.

Hadis dari 'Abdullah bin 'Abbas ra dia berkata:"Rasulullah Saw bersabda kepadaku pada pagi hari 'Aqabah (hari melempar jumrah pertama dalam rangkaian ibadah haji), dan saat itu beliau berada di atas kendaraannya:"Kemarilah, ambilkan (kerikil) untukku" Maka aku ambilkan untuk beliau kerikil-kerikil, dan kerikil-kerikil itu (yang aku ambil) adalah batu-batu (agak besar) yang digunakan untuk melempar ketapel, maka ketika aku letakkan di tangan beliau, beliau berkata:

(Jangan batu ini) Namun dengan (kerikil) yang seperti mereka, dengan yang seperti

\footnotetext{
${ }^{21}$ Zakky Mubarak, Riyāẹ al-Mu'min (Jakarta: Yayasan Ukhuwah Insaniyah, 2010), 157.
} 
mereka. Waspadalah kalian dari sikap ghuluw dalam beragama, karena sesungguhnya yang membinasakan umat-umat sebelum kalian adalah ghuluw dalam beragama". (HR. Al-Tabrani) ${ }^{22}$

Pemahaman keliru dari sementara muslim bahwa melempar jumrah adalah upaya melempari dan menyakiti setan. Jadi dengan menggunakan batu yang lebih besar maka setan akan lebih tersakiti. Padahal melempar jumrah hanya merupakan simbol membuang sifat setaniyah dalam diri dan berikrar menjadikan setan adalah musuh yang nyata. Hadis ini adalah salah satu dalil yang paling gamblang dalam melarang sikap ghuluw dalam beragama secara keseluruhan. Dan hal itu, sekalipun momen larangannya dalam masalah berlebih-lebihan dalam kerikil untuk melempar jumrah, hanya saja Nabi Saw. melontarkan ucapan tersebut dengan lafal umum yang mencakup seluruh larangan dari sikap ghuluw dalam segala bidang agama.

d. Kisah Zainab binti Jahsy ra Istri Rasulullah Saw.

Anas bin Malik ra menceritakan bahwa suatu ketika Nabi Saw. masuk masjid. Tibatiba beliau mendapatkan tali yang terbentang antara dua tiang. Beliau pun berkata, "Tali apa ini?" Mereka menjawab, "Ini adalah tali milik Zainab, jika ia telah kecapaian, ia bergantungan pada tali itu." Rasulullah Saw bersabda, "Lepaskan tali tersebut. Hendaklah salah seorang dari kalian melakukan salat ketika segar, dan jika telah lelah, hendaklah ia istirahat "(Muttafaq Alaihi).

Hadis di atas merupakan dalil bagi kita untuk tidak berlebihan dalam ibadah, membebani diri dengan sesuatu yang tidak kita mampu. Karena dalam kondisi di luar kemampuan, bisa jadi pikiran kita kacau, salah dalam bacaan salat, atau bisa jadi jatuh sakit sehingga keesokan hari kita tidak bisa lagi beribadah. Maka Rasulullah memberikan kita resep: salatlah ketika segar, dan tidurlah ketika lelah. ${ }^{23}$

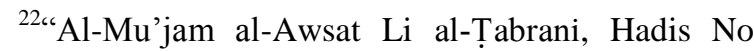
2246," n.d.

${ }^{23}$ Mubarak, Riyậ̣ al-Mu'min, 159. e. Kisah Muadz bin Jabal Memperpanjang Bacaan Ketika Jadi Imam Salat Berjamaah.

Di masa Nabi Muhammad Saw ada seorang sahabat yang memimpin salat, lantas jamaah di belakangnya lari karena bacaan yang terlalu panjang. Mu'adz bin Jabal Al-Anshari pernah memimpin salat Isya. Ia pun memperpanjang bacaannya. Lantas ada seseorang di antara kami yang sengaja keluar dari jama'ah. Ia pun salat sendirian. Mu'adz pun dikabarkan tentang keadaan orang tersebut. Mu'adz menyebutnya sebagai seorang munafik. Orang itu pun mendatangi Rasulullah Saw dan mengabarkan pada beliau apa yang dikatakan oleh Mu'adz padanya. Nabi Saw lantas menasehati Mu'adz:

Apakah engkau ingin membuat orang lari dari agama, wahai Mu'adz? Jika engkau mengimami orang-orang, bacalah surat AlShams, Al-Duha, Al-A'lā, Al-'Alaq, atau Al-Lail." (HR. Muslim). ${ }^{24}$

\section{f. Kisah Beberapa Sahabat Nabi Saw} Berpuasa Wișal.

Puasa wișal adalah menyambungkan puasa ke hari berikutnya tanpa berbuka di malam hari. Suatu saat diriwayatkan ada beberapa sahabat Rasul berpuasa wișal karena mengharap pahala yang berlebih dari Allah Swt. Rasulullah Saw melarang praktik tersebut karena dapat melemahkan fisik dan memperberat ibadah. Imam Ahmad meriwayatkan dari Abu Hurairah dia berkata bahwa Rasulullah Saw bersabda, "Janganlah kamu puasa wisal". Para sahabat barkata, "Wahai Rasulullah, engkau sendiri melakukannya." Nabi bersabda," Sesungguhnya akau berbeda dengan kalian, pada malam hari Dia memberiku makan dan minum."

Telah menjadi ketetapan bahwa puasa wiṣal dilarang. Puasa wișal merupakan ibadah khusus bagi Nabi Saw. Namun wiṣal sampai sahur dibolehkan karena ada riwayat yang menyatakan hal tersebut. ${ }^{25}$

\section{g. Kisah Para Sahabat Nabi Saw Menghina} Pelaku Maksiat.

\footnotetext{
${ }^{24}$ Muslim bin Hajjaj al-Qusyairi Al-Nisaburi, “AlJāmi’ Al-Șahịih, Hadis No. 465," Islamweb.net, n.d.

25"Musmad Ahmad Bin Hanbal, Hadis No 8342," Islamweb.net, n.d.
} 
Kisah ini diriwayatkan dari Abu Hurairah r.a dalam Sahih al-Bukhari tentang salah seorang sahabat yang meminum khamr. Setelah dicambuk oleh Nabi Saw, sang peminum khamr pulang dan sekelompok para sahabat. Beberapa sahabat kemudian mencacinya, menghardiknya dan menghinanya sebagai pendosa, dan melaknatnya, serta mendoakannya jauh dari rahmat Allah Swt. Mendengar hinaan yang diucapkan para sahabat itu, Rasul langsung menegurnya dan mengatakan, " Janganlah kalian jadi penolong setan atas saudaramu itu!"26

Imam Ibnu Hajar dalam Fatḥul Bāri menjelaskan maksud kata-kata, "Jangan jadi penolong setan" adalah bahwa setan ingin menggoda manusia dengan kemaksiatan. Ketika ada orang bermaksiat, maka timbul kemarahan orang lain. Karena marah kemudian ia caci maki, hina temannya. Itulah tujuan setan mendoakan dan menebarkan keburukan. Jadi orang yang menghina temannya seolaholah sudah membantu setan merealisasikan tujuannya. $^{27}$

h. Kisah Reaksi Umar bin Khatab Ra. Mendengar Wafatnya Rasulullah Saw.

Kabar wafat Rasulullah Saw yang didengar Umar bin Khattab ra telah membuatnya marah dan mengeluarkanya dari kesadaran. Beliau berdiri dan bersuara dengan lantang:

Laki - laki dari kaum munafik membuat isu bahwa Rasulullah Saw telah wafat. Rasulullah Saw sesungguhnya masih hidup. Ia hanya pergi menemui Rabbnya sebagaimana Musa bin Imran pergi meninggalkan kaumnya selama empat puluh hari, kemudian kembali kepada mereka, dan itu setelah diisukan bahwa ia telah mati. Demi Allah, Rasulullah Saw akan kembali dan akan memotong tangan dan kaki laki-laki yang menyebarkan isu bahwa beliau telah wafat.

Umar RA karena terlalu cintanya kepada Rasulullah, mendorongnya saat itu untuk tidak percaya akan takdir Allah Swt. Akan tetapi

\footnotetext{
26“"Sahih Bukhari, Hadis No. 6283," diakses pada 04 Februari 2016, http://library.islamweb.net/hadith/display-_hbook.php?bk_no=394\&pid=222523\&hid=.

${ }^{27}$ Asqalani, Fathul Bāri.
}

setelah mendapat nasehat dari Abu Bakar ra., maka Umarpun tersadar bahwa Nabi Muhammad Saw. juga manusia yang dapat mengalami kematian kapanpun. Abu Bakar kala itu mengingatkan:

Barangsiapa di antara kalian yang menyembah Muhammad, maka sesungguhnya Muhammad telah wafat. Dan barang siapa di antara kalian yang menyembah Allah, maka sesungguhnya Allah hidup dan takkan pernah mati. Allah berfirman, Muhammad itu tidak lain hanyalah seorang rasul, sungguh telah berlalu sebelumnya beberapa orang rasul. Apakah Jika dia wafat atau dibunuh kamu berbalik ke belakang? Barangsiapa yang berbalik ke belakang, maka ia tidak dapat mendatangkan mudharat kepada Allah sedikitpun, dan Allah akan memberi balasan kepada orangorang yang bersyukur. ${ }^{28}$

\section{Eksremitas Sahabat dan Status Generasi Terbaik Umat}

Berbagai riwayat yang penulis paparkan di atas bukanlah bertujuan untuk mendegradasi kemuliaan para Sahabat Rasulullah. Sesungguhnya generasi terbaik dari umat ini ialah generasi para sahabat Rasulullah. Mereka adalah orang orang yang terbaik keimanan dan ketaqwaannya kepada Allah dan Rasul-Nya, serta paling gigih dalam memperjuangkan agama ini dan paling besar pengorbanannya untuk Allah dan Rasul-Nya. Pantas jika Allah Swt telah memuji mereka dalam Alquran, ${ }^{29}$ dan begitu pula Nabi Saw juga telah memuji mereka dalam sabda-sabdanya, bahkan menjadikan mereka sebagai suri tauladan yang harus diikuti dan dicontoh dalam hal memahami dan mengamalkan agama ini. Penghormatan kita terhadap para Sahabat, tidaklah menafikan bahwa mereka juga manusia biasa.

Dari analisa penulis, kekeliruan yang dilakukan para sahabat umumnya adalah hal yang wajar dan dimaklumi. Mengingat mereka

\footnotetext{
${ }^{28}$ Chaerul Akhmad, "Sejarah Hidup Muhammad Saw: Umar Tak Percaya Nabi Wafat," Republika Online, n.d.: Q.S. Ali Imran: 144.

${ }^{29}$ Q.S. 9:100.
} 
merupakan orang-orang yang patuh, sangat ingin meraih keutamaan dalam mengamalkan ajaran agama. Totalitas ketaatan pada Allah dan Rasul-Nya, pada nilai-nilai agama menjadikan mereka kadang terlena mempraktikkan dosis yang berlebih dari yang seharusnya. Namun ketika mereka mendapatkan teguran dari Rasulullah, serta merta mereka kembali pada rel ajaran Islam yang lurus.

Sahabat adalah orang yang hidup di masa ayat-ayat Alquran diturunkan Allah melalui malaikat Jibril untuk diwahyukan kepada Nabi Muhammad Saw. Meski mereka hadir pada zaman wahyu, namun boleh jadi mereka keliru memahami ayat saat itu, karena belum mendapat penjelasan dan contoh langsung dari Nabi Saw tentang maksud dan tujuan serta penerapan dari ayat-ayat Alquran yang diturunkan itu. Sikap ghuluw yang muncul dari sahabat hanyalah noktah kecil yang tidak sampai menimbulkan perpecahan apalagi kekerasan diantara mereka. Mereka merupakan generasi yang sangat menghormati perbedaan pengamalan agama. Kalaupun terjadi perselihan, maka keputusan Rasulullah merupakan rujukan akhir yang sangat dipatuhi oleh berbagai pihak yang bersengketa. Oleh karena itu dapat kita pahami, bahwa di masa Rasulullah benih-benih ekstremitas beragama tidak berubah menjadi bola liar atau membesar. Berbeda halnya dengan masa selanjutnya, sepeninggal Rasulullah, pemahaman ekstrem dapat berkembang dan menguat menjadi kelompok-kelompok yang berseberangan. Seperti yang kita ketahui dalam sejarah pada masa Khulafaurrasyidin eskalasi ekstremitas beragama semakin membesar. Muncullah berbagai macam kelompok seperti Kaum Khawarij, Syiah, Qadiriyah dsb. Tidak jarang antar kelompok tersebut saling menyalahkan bahkan mengkafirkan satu sama lainnya.

Sikap ekstrem dipertontonkan kaum Khawarij yang berani mengkafirkan sebagian sahabat Nabi Saw. Kaum Khawarij terkenal sebagai kelompok garis keras yang memahami teks-teks Alquran dan Hadis secara harfiah. Contoh bahaya dari pemahaman yang tidak lurus ini, dapat dilihat pada diri 'AbdurRahmaan bin Muljam. Sosok ini telah teracuni pemikiran Khawaarij. Sejarah mencatat kejahatan kaum Khawarij ini telah melakukan pembunuhan terhadap Amirul-Mukminin 'Ali bin Abi Thalib, yang juga keponakan Rasulullah.

Abdurrahman bin Muljam al-Himyari, pelaku pembunuhan terhadap Ali bin Abi Talib saat membunuh dengan pedangnya dia sempat membaca ayat Alquran. "Tidak ada hukum kecuali hukum Allah" Satu syiar dan simbol yang biasa didengung-dengungkan oleh orang-orang dari kalangan Kharijiah atau Khawarij. Jangan beranggapan Abdurrahman bin Muljam adalah seorang kafir atau musyrik. Ia seorang muslim berpaham khawarij bahkan tercatat sebagai orang yang sangat serius beragama. Taat beribadah. Ia selalu berpuasa di siang hari, salat sepanjang malam dan hafal Alquran. Maka Ibnu Taimiyah berkata:

Seseorang yang membunuh Ali iapun menegakkan salat, melakukan puasa, membaca Alquran. Ia membunuh Ali dengan anggapan bahwa hal itu akan mendapat ridho Allah dan Rasul-Nya."30

\section{SIMPULAN}

Simpulan yang dapat diambil setelah melakukan penelitian tentang sikap ghuluw dalam Islam sebagai benih ekstremisme beragama sejak masa Rasulullah Saw. adalah sebagai berikut:

Pertama, ciri-ciri ektremitas dalam beragama adalah sebagai berikut:

1. Fanatik terhadap salah satu pandangan.

2. Cenderung mempersulit dan memperberat praktik keagamaan.

3. Berprasangka buruk kepada orang lain, yang berbeda mazhab teologi atau mazhab fikihnya.

4. Suka mengkafirkan orang lain yang berbeda aliran teologinya, seperti yang terjadi pada kelompoki khawarij.

Kedua, faktor-faktor yang dapat menimbulkan ekstremitas dalam beragama adalah:

1. Sebab-sebab yang berkaitan dengan metodologi ilmiah.

\footnotetext{
${ }^{30}$ Musthafa Abdul Wahid, "Sang Pembunuh Imam Ali RA," Kisahmuslim.com, n.d.
} 
2. Sebab-sebab yang berkaitan dengan aspek kejiwaan dan pendidikan.

3. Sebab-sebab yang berkaitan dengan aspek sosial dan problematika dunia.

Faktor pertama yang berkaitan dengan metodologi ilmiah yang dimaksud melingkupi kebodohan dalam ajaran Islam. Ekstremitas dalam beragama sering muncul dari seseorang yang terlalu semangat mengamalkan ajaran agama, tetapi minim ilmu. Ia mempelajari ajaran Islam secara parsial, tidak secara menyeluruh.

Faktor Kedua yang berkaitan dengan aspek kejiwaan dan pendidikan mencakup tabiat dan lingkungan yang keras. Munculnya sikap ekstrem di kalangan Khawarij karena kebanyakan mereka berasal dari suku Badui Arab yang keras dan hidup nomaden mengarungi kehidupan padang pasir yang ganas dan tandus membuat mereka bersifat sederhana dalam cara hidup dan pemikiran, tetapi keras hati, berani, dan bersikap merdeka, tidak bergantung pada orang lain.

Faktor yang ketiga berhubungan dengan aspek soial, ekonomi, politik dan problematika kehidupan dunia. Ketidakpuasan terhadap kondisi umat Islam yang terpuruk secara sosial-ekonomi sering menjadi alasan kelompok radikal untuk bertindak ekstrem. Rusaknya akidah umat, hilangnya syariat Islam di mayoritas negara-negara muslim mendorong mereka ingin memulihkannya. Apalagi mereka mensinyalir bahwa keterpurukan umat Islam lebih disebabkan oleh hegemoni politik dan ketidakadilan dunia Barat terhadap dunia Islam.

Sejumlah kisah di masa Rasulullah Saw. telah memperlihatkan bahwa sikap ekstrem sudah mulai muncul dalam praktik beragama sebagian sahabat Nabi. Meskipun penyimpangan ini masih dalam tataran individu dan skala yang kecil. Umumnya kekeliruan terjadi lantaran semangat yang kuat dari sahabat ingin mengamalkan Islam secara total. Ketika gejala ekstremitas ini muncul di hadapan Nabi Saw, maka Nabi segera meluruskan dan para sahabatpun mengkoreksi kekeliruan mereka, dan kembali istiqāmah ke jalan yang lurus.
Dari analisa penulis, ekstremitas dalam beragama yang dilakukan oleh para sahabat umumnya adalah hal yang wajar dan dapat dimaklumi. Sikap ekstrem yang muncul dari sahabat hanyalah noktah kecil yang tidak sampai menimbulkan perpecahan apalagi kekerasan diantara mereka. Mereka merupakan generasi yang sangat menghormati perbedaan pengamalan agama. Kalaupun terjadi perselihan, maka keputusan Rasulullah merupakan rujukan akhir yang sangat dipatuhi oleh berbagai pihak yang bersengketa. Oleh karena itu dapat kita pahami, bahwa di masa Rasulullah benih-benih ekstremitas beragama tidak berubah menjadi bola liar atau membesar.

Namun, berbeda dengan sikap ekstrem yang dipertontonkan oleh kaum Khawarij yang berani mengkafirkan sebagian sahabat Nabi Saw. Kaum Khawarij terkenal sebagai kelompok garis keras yang memahami teksteks Alquran dan Hadis secara harfiah. Contoh bahaya dari pemahaman yang tidak lurus ini, dapat dilihat pada diri 'Abdur- Rahmaan bin Muljam. Sosok ini telah teracuni pemikiran Khawaarij. Sejarah mencatat kejahatan kaum Khawarij ini telah melakukan pembunuhan terhadap Amirul-Mukminin 'Ali bin Abi Thalib.

Nabi Muhammad Saw. telah memberi tuntunan ideal tentang bagaimana kita menjalankan agama Islam. Melalui koreksi atas praktik sahabatnya yang keliru, ia memberikan terapi atas kecenderungan melampaui batas menjalankan agama. Sikap ekstrem melampai batas tidak dibenarkan oleh syariat Islam. Karena di antara karakteristik mendasar Islam adalah wasatiyyah atau bersifat pertengahan. Dalam arti, ajaran Islam selalu menekankan aspek proporsional dan keseimbangan dalam berbagai aplikasi ajarannya. Moderat dalam beragama adalah tenang, seimbang dan konsisten serta mengambil jalan tengah dalam semua urusan agama tanpa melebihkan/menambah dan tanpa mengurangi/ mengabaikannya. Kemoderatan dalam beragama bersumber dari ajaran Islam yang lurus dan benar dan sesuai dengan fitrah manusia. Islam merupakan agama konprehensif, kombi- 
nasi yang seimbang anatara Akidah, Syariat dan Akhlakul Karimah.

Islam adalah agama yang senantiasa menjaga keharmonisasan dan keseimbangan antara kebutuhan jasmani dan ruhani, antara kebutuhan individu dan masyarakat, dan antara kebutuhan dunia dan akhirat. Islam mengajarkan umatnya untuk selalu berada di tengah dan menempuh jalan tengah, dan sikap itu harus direalisasikan dalam segala hal, sebagaimana Hadis Rasulullah Saw. yang diriwayatkan oleh Imam Ahmad, "Sebaikbaiknya perkara adalah yang pertengahan." Dengan kata lain, sebagai agama pilihan, Islam melarang umatnya bertindak berlebihan, semena-mena, melampaui batas, bertindak fanatis, mendahulukan kepentingan individu dan golongan di atas kepentingan orang banyak, apalagi berlaku ekstrem dan melakukan kekerasan. Umat Islam saat ini sangat membutuhkan metode dan sikap moderat untuk menyelamatkan mereka dari berbagai pandangan yang ekstrem dan berlebihan terutama dalam bidang hukum. Sikap ekstrem dan kaku dalam menetapkan hukum ini telah menimbulkan kekacauan dalam pemikiran dan ketentuan-ketentuan hukum.

\section{DAFTAR PUSTAKA}

Abdul Wahid, Musthafa. "Sang Pembunuh Imam Ali RA." Kisahmuslim.com, n.d.

Akhmad, Chaerul. "Sejarah Hidup Muhammad Saw: Umar Tak Percaya Nabi Wafat." Republika Online, n.d.

Al-Bukhari, Muhammad bin Isma'il al-Ju'fi. “Al-Jāmi’ Al-Ṣaḥih, Hadis No.38,” n.d.

"Al-Mu'jam Al-Awsat Li Al-Tabrani, Hadis No 2246," n.d.

Al-Nisaburi, Muslim bin Hajjaj al-Qusyairi. “Al-Jāmi” Al-Sahịih, Hadis No. 465." Islamweb.net, n.d.

Asqalani, Ibnu Hajar. Fathul Bārī. Vol.12. Kairo: Darul Rayyan Lil Turats, 1988.

Ibnu Kathï, Imaduddin Abul Fida'. Tafsir AlQur'ān Al-'Azìm. Vol. 2. Kairo: Darul Kutub al-Misriyah, 1988.

Islam Web. "Sahih Muslim, Hadis No. 4829." Islamweb.net, n.d.

Jauziyyah, Ibn al-Qayyim. Madarij Al-Sālikīn
Bayna Manāzil Iyyāka Na’budu Wa Iyyāka Nasta’īn. Kairo: Darut Turath, 1992.

Jawas, Yazid bin Abdul Qadir. "Larangan Ghuluw Dalam Beragama." manhaj.or.id, t.t.

Luwaihiq, Abdurrahman bin Mu'alla. Ghuluw Benalu Dalam BerIslam. Jakarta: Darul Falah, 2014.

Manzur, Ibnu. Lisānul 'Arab. Vol. 15. Beirut: Darul Ihya Turats al Arabi, 1985.

Mas'ud, Abdurrahman. Menuju Paradigma Islam Humanis. Yogyakarta: Gama Media, 2003.

Mubarak, Zakky. Riyād Al-Mu'min. Jakarta: Yayasan Ukhuwah Insaniyah, 2010.

"Musnad Ahmad Bin Hanbal, Hadis No 8342." Islamweb.net, t.t.

Qardhawi, Yusuf. Al-Khașā'is Al-Āmmah Li Al-Islām. Kairo: Maktabah Wahbah, 1996.

- Sạ̣wah Al-Islāmiyyah Bayna AlJumūd Wa Al-Tatarruf. Kairo: Dar el Shorouk, 2001.

"Sahih Bukhari, Hadis No. 6283," t.t.

"Sahih Bukhari, Hadis No.68," t.t.

"Sunan Abu Daud, Hadis No.4260." Islamweb.net, t.t.

Taher, Tarmizi. "Anatomi Radikalisme Keagamaan Dalam Sejarah Islam." In Radikalisme Agama, edited by Bahtiar Effendi and Hendro Prasetyo. Jakarta: PPIM, 1998.

Thabari, Ibnu Jarir. Jāmi’ Al-Bayān Fì Ta’wīl Ayat al-Qur'ān. Vol. 4. Beirut: Darul Ihya lil Turats, t.t.

Tim Penyusun Kamus Bahasa. Kamus Besar Bahasa Indonesia. Edisi 3. Jakarta: Balai Pustaka, 2002.

Zuhaili, Muhammad. Moderat Dalam Islam. Jakarta: Penerbit Akbar Media, 2012.

\section{Internet:}

Abdul Wahid, Musthafa. "Sang Pembunuh Imam Ali RA." kisahmuslim.com. Diakses pada 16 April 2015. https://kisahmuslim.com/3306-sangpembunuh-imam-ali.html. 
Akhmad, Chaerul. "Sejarah Hidup Muhammad Saw: Umar Tak Percaya Nabi Wafat." Republika Online. Diakses pada 4 Februari 2016. http://www.republika co.id/berita/duniaislam/khazanah/12/03/1 4/m0vbz4-sejarah-hidup-muhammadSaw-umar-tak-percaya-nabi-wafat.

Al-Bukhari, Muhammad bin Isma'il al-Ju'fi. “Al-Jāmi' al-Ṣahịh, Hadis No.38." Diakses pada 4 Februari 2016. http:// www.islamweb.net/mainpage/index.php.

"Al-Mu'jam Al-Awsat Li al-Tabrani, Hadis No 2246." Diakses pada 4 Februari 2016. http:/hadith/display_hbook.php?bk_no $=47$ $5 \&$ hid=2246\&pid=280459 .

Al-Nisaburi, Muslim bin Hajjaj al-Qushairi. "Al-Jāmi' al-Ṣahịh, Hadis No. 465." Islamweb.net. Diakses pada 3 Februari 2016.http://www.islamweb.net/mainpage/ index.php.
"Sahih Bukhari, Hadis No. 6283." Diakses pada 4 Februari 2016. http: //library.islamweb.net/hadith/-display_hbook.php?bk_no=394\&pid=222523\&hi $\mathrm{d}=$.

"Sahih Bukhari, Hadis No.68." Diakses pada 4 Februari 2016. http//www. library.islamweb.net/hadith/display_hboo k.-php?bk_no=146\&hid=68\&pid=97769.

"Sunan Abu Daud, Hadis No.4260." islamweb.net. Diakses pada 4 Februari 2016. http//www. library.islamweb. net/hadith/-display-_hbook.php?bk_no= $184 \&$ hid $=4260 \&$ pid $=117049$. 